\title{
PENGARUH KONSENTRASI GULA TERHADAP ORGANOLEPTIK DAN SIFAT KIMIA ANGGUR BUAH TOMI-TOMI (Flacourtia inermis Roxb)
}

\section{The Effect of Sugar Consentrate to Organoleptic and Chemical Characteristic of Grape Tomi-Tomi (Flacourtia inermis Roxb)}

\section{Rachel Breemer*, Erynola Moniharapon, dan James Nimreskosu}

\author{
Jurusan Teknologi Hasil Pertanian Fakultas Pertanian Universitas Pattimura \\ Jl. Ir. M. Putuhena Kampus Poka Ambon 97233. \\ * Penulis Korespondensi: E-mail: rachelbreemer@yahoo.com
}

\begin{abstract}
This research was aimed to determine the exact sugar concentration on the organoleptic and chemical properties of tomi-tomi fruit wine. A completely randomized experimental design with three levels sugar concentration 30, 40, and 50\% were repeat three times therefore there were a total of nine experimental units. Result showed that $50 \%$ sugar concentration had the best organoleptic characteristic that was able to produce wine having $1,27 \%$ ethyl alcohol, 21,23\% sugar content and a pH of 3,6.
\end{abstract}

Keywords: fruit grape, sugar concentrate, fermentation, alcohol, tomi-tomi

\begin{abstract}
ABSTRAK
Penelitian ini bertujuan untuk menentukan konsentrasi gula yang tepat terhadap organoleptik dan sifat kimia anggur buah tomi-tomi. Rancangan percobaan yang digunakan dalam penelitian adalah Rancangan Acak Lengkap dengan satu faktor yakni konsentrasi gula (\%) yang terdiri dari tiga taraf perlakuan yaitu 30, 40, dan $50 \%$, masing-masing perlakuan diulang sebanyak tiga kali sehingga jumlah satuan percobaan adalah sembilan satuan. Berdasarkan hasil uji organoleptik perlakuan terbaik yang diperoleh adalah konsentrasi gula $50 \%$ dan dilanjutkan dengan uji kimia menghasilkan kadar etil alkohol sebesar 1,27\%, kadar gula 21,23\%, dan $\mathrm{pH} 3,6$.
\end{abstract}

Kata kunci: anggur buah, konsentrasi gula, fermentasi, alcohol, tomi-tomi

\section{PENDAHULUAN}

Pengolahan buah tomi-tomi menjadi anggur buah merupakan salah satu alternatif untuk mengawetkan dan menganekaragamkan produk olahan dari buah tomi-tomi, sehingga dapat menambah variasi produk dari buah tomi-tomi. Anggur buah adalah minuman beralkohol yang diperoleh dari hasil fermentasi buah-buahan seperti nanas, markisa, salak, pisang, jeruk dan lain-lain (Pawignya et al., 2010). Produksi minuman anggur dapat dilakukan melalui proses fermentasi alkohol dari sari buah tomi-tomi.

Proses fermentasi ini dapat berjalan dengan bantuan mikroba yang mengubah karbohidrat atau gula menjadi alkohol. Mikroba yang digunakan dalam penelitian ini adalah mikroba Saccharomyces cerevisiae. S.cerevisiae adalah salah satu jenis ragi yang biasanya digunakan untuk memecah gula menjadi alkohol dan $\mathrm{CO}_{2}$. Proses ini nantinya akan terjadi secara anaerob (tanpa oksigen) dan disebut sebagai fermentasi alkohol (Gaman dan Sherirington, 1992).

Komponen utama yang merupakan syarat terbentuknya anggur buah adalah gula yang difermentasi oleh S.cerevisiae menjadi etanol dan $\mathrm{CO}_{2}$. Gula secara alami di dalam bahan pangan biasanya tidak cukup tinggi untuk menghasilkan kadar etanol yang memenuhi syarat mutu anggur buah, sehingga perlu ditambahkan dari luar. Banyaknya gula yang digunakan perlu diketahui karena konsentrasi gula yang terlalu tinggi akan 
mengakibatkan kematian khamir sehingga proses fermentasi tidak akan berlangsung dengan baik. Dalam proses fermentasi, gula mempunyai peranan sebagai sumber karbon dalam metabolisme yeast. Aktivitas yeast berhubungan dengan konsentrasi gula yang ditambahkan (Wahono et al., 2011).

Penelitian anggur buah yang telah dilakukan antara lain: anggur apel reject (Ariyanto et al., 2013), anggur buah rambutan (Widiaastuti dan Eska, 2010), anggur buah jambu mete (Santi, 2008), dan anggur buah salak (Gunam et al., 2009). Pada proses pembuatan anggur buah salak variabel yang diamati adalah kadar etanol. Sedangkan perlakuan yang dipakai yaitu jenis dan jumlah penambahan gula. Menurut Rahayu dan Kuswanto (1998), pada proses pembuatan anggur buah pada umumnya gula yang digunakan maksimum $30 \%$.

Berdasarkan uraian diatas maka penulis tertarik untuk melakukan penelitian tentang pengaruh konsentrasi gula terhadap organoleptik dan sifat kimia anggur buah tomi-tomi.

\section{METODE PENELITIAN}

\section{Bahan}

Bahan yang digunakan adalah buah tomitomi yang diperoleh dari Negeri Kilang Kecamatan Leitimur Selatan Kota Ambon, Saccharomyces cerevisiae, dan gula pasir.

\section{Rancangan Percobaan}

Rancangan percobaan yang digunakan dalam penelitian adalah Rancangan Acak Lengkap dengan tiga taraf perlakuan konsentrasi gula antara lain $30 \%$, 40\%, dan 50\%. Setiap satuan percobaan diulang sebanyak tiga kali sehingga jumlah satuan percobaan adalah 9 satuan percobaan.

\section{Pembuatan Anggur Tomi-Tomi}

Proses pembuatan anggur buah tomi-tomi mengikuti metode Gunam et al. (2009) yang telah dimodifikasi. Untuk memperoleh sari buah tomitomi, buah tomi-tomi dicuci, dan dikupas untuk membuang kulit dan bijinya. Penambahan air dengan perbandingan antara daging buah tomi-tomi dan air sebanyak 1:3, kemudian dihancurkan (blender) dan disaring menggunakan kain sifon, selanjutnya filtrat dimasak hingga mendidih (pasteurisasi) kurang lebih 30 menit. Ukur sebanyak $500 \mathrm{~mL}$, ditambahkan gula (sesuai perlakuan), filtrat kemudian didinginkan sampai mencapai suhu $30^{\circ} \mathrm{C}$, setelah itu sari buah disaring, nilai $\mathrm{pH}$ awal diatur hingga 3,75 (untuk meningkatkan $\mathrm{pH}$ digunakan $\mathrm{NaOH}$ dan untuk menurunkan $\mathrm{pH}$ digunakan $\mathrm{C}_{6} \mathrm{H}_{8} \mathrm{O}_{7}$ ). Ditambahkan ragi $5 \%(b / v)$ pada setiap perlakuan. Selanjutnya dimasukkan ke dalam botol kemudian difermentasi selama 14 hari.

\section{Pengamatan Anggur Tomi-Tomi}

\section{Uji organoleptik Untuk Tingkat Kesukaan (Uji Hedonis)}

Uji organoleptik dilakukan dengan menggunakan panelis sebanyak 30 orang. Panelis memberikan penilaian terhadap warna, aroma, rasa dan tingkat kesukaan dengan menggunakan skala hedonik dan skala numerik secara visual.

\section{Analisis Total Gula}

Larutan sebanyak $1 \mathrm{~mL}$ dimasukkan ke dalam tabung reaksi yang berisi $5 \mathrm{~mL}$ antrhone (0,05 g dalam $50 \mathrm{~mL} \mathrm{H}_{2} \mathrm{SO}_{4}$ pekat) kemudian ditutup dengan plastik, dihomogenkan, dan dipanaskan pada suhu $100^{\circ} \mathrm{C}$ selama 12 menit, setelah itu didinginkan dengan cepat pada air mengalir, dibaca menggunakan spektrofotometer pada panjang gelombang $540 \mathrm{~nm}$.

\section{Analisis pH}

Analisis $\mathrm{pH}$ menggunakan $\mathrm{pH}$ meter dimana sebanyak $30 \mathrm{~mL}$ sampel di ambil dan ditempatkan dalam beaker glass $50 \mathrm{~mL}$, sebelum digunakan alat dikalibrasi terlebih dahulu menggunakan larutan buffer $\mathrm{pH} 4$ dan $\mathrm{pH} 7$ dan dibersihkan dengan aquades, selanjutnya dilakukan pengukuran $\mathrm{pH}$ terhadap sampel.

\section{Penentuan Kadar Alkohol}

Kadar alkohol dihitung sebagai etil alkohol. Diambil contoh sebanyak $100 \mathrm{~mL}$ dalam labu suling kemudian didestilasi. Hasil destilasi ditampung dengan piknometer sampai tanda garis. Piknometer didinginkan pada suhu $25^{\circ} \mathrm{C}$ selama 15 menit kemudian ditimbang. Sebagai pembanding dihitung berat piknometer kosong dan berat air pada suhu $25^{\circ} \mathrm{C}$. Dari Tabel hubungan antara kadar alkohol dengan berat jenis pada berbagai suhu menunjukkan kadar etil alkohol pada sampel. 


\section{HASIL DAN PEMBAHASAN}

\section{Pengaruh Perlakuan Terhadap Sifat Organoleptik Anggur Tomi-Tomi}

Uji organoleptik adalah penilaian terhadap suatu produk makanan atau minuman dengan menggunakan alat indera manusia untuk mengukur sifat sensorik dari makanan atau minuman tersebut. Pengujian inderawi dilakukan untuk mengetahui seberapa besar daya terima panelis terhadap anggur buah tomi-tomi.

\section{Warna}

Warna pada makanan atau minuman dapat disebabkan oleh beberapa sumber diantaranya adalah pigmen, pengaruh panas pada gula (karamel), dan adanya reaksi antara gula dan asam amino (reaksi maillard) dan adanya pencampuran bahan lain (Winarno, 2004). Secara visual, faktor warna sangat menentukan mutu. Warna juga dapat menarik perhatian para konsumen sehingga dapat menilai atau memberi kesan suka atau tidak suka.

Pemberian gula sebanyak 50\% dengan kriteria agak merah sampai merah berbeda nyata dengan dua perlakuan lainnya. Nilai rata-rata warna terendah terdapat pada konsentrasi gula $40 \%$ (berwarna tidak merah sampai agak merah) dan tidak berbeda nyata dengan perlakuan gula $30 \%$ tetapi berbeda nyata dengan konsentrasi gula $50 \%$.

Tingginya penilaian panelis terhadap perlakuan gula $50 \%$ terjadi karena perlakuan tersebut menghasilkan warna agak merah sampai merah, warna ini lebih disukai panelis dibandingkan dengan warna agak merah dan tidak merah serta agak pekat dan keruh yang dihasilkan oleh perlakuan lainnya yakni pemberian gula $30 \%$ dan $40 \%$. Hal ini disebabkan karena lebih banyak pemberian gula yang dapat membantu proses pembentukan warna kemerahan dan tidak keruh pada saat fermentasi. Terbukti pada konsentrasi gula 50\% warna yang dihasilkan lebih menonjol bila dibandingkan dengan perlakuan lain.

\section{Aroma}

Aroma umumnya didapat dengan menganalisa hasil penciuman. Aroma mempunyai peranan yang sangat penting dalam penentuan derajat penilaian dan kualitas suatu bahan pangan. Selain rasa dan warna, bau atau aroma akan berpengaruh dan menjadi perhatian utama (Rubianty dan Kaseger, 1985).

Nilai aroma rata-rata tertinggi terdapat pada konsentrasi gula 50\% (beraroma alkohol), sedangkan nilai rata-rata terendah berada pada perlakuan gula 30\% (agak beraroma alkohol). Tingginya penilaian panelis terhadap aroma yang dihasilkan oleh perlakuan gula 50\% karena pada perlakuan ini menghasilkan aroma alkohol dibandingkan dengan dua perlakuan lainnya. Hal ini disebabkan peningkatan jumlah gula yang akan meningkatkan kadar alkohol dan asam volatil yang merupakan komponen utama pembentuk aroma. Menurut Kourkoutas et al. (2006), aroma anggur buah ditentukkan oleh senyawa volatil seperti asam-asam lemak, alkohol, dan ester, dimana ester ini menjadi komponen utama pembentukkan aroma dan flavour. Komponen aroma anggur buah terbagi atas dua yaitu diturunkan dari bahan baku dan dihasilkan dari proses fermentasi (Said, 1987).

\section{Rasa}

Rasa merupakan petunjuk untuk menilai suatu makanan atau minuman apakah enak, manis, asin, atau pahit. Menurut Winarno (2002), rasa lebih banyak menggunakan panca indera lidah, indera pencicip berfungsi untuk menilai rasa dengan cara cicip untuk suatu makanan dan minuman. Nilai rata-rata tertinggi terdapat pada perlakuan gula $50 \%$ dengan rasa agak manis, sedangkan nilai terendah pada perlakuan $30 \%$ dengan rasa tidak manis. Penilaian panelis terhadap rasa anggur tomi-tomi meningkat dengan semakin besarnya pemberian gula, hal ini disebabkan karena kombinasi rasa manis, asam, sepat, dan alkohol yang dirasakan oleh panelis. Rasa manis pada perlakuan gula $50 \%$ disebabkan karena pada perlakuan ini masih menyisakan sisa gula yang tidak habis difermentasikan oleh khamir. Hal ini disebabkan karena kondisi buah yang sangat asam dan pemberian $50 \%$ serta lama waktu 14 hari belum optimum untuk S.cerevisiae dalam memproduksi alkohol yang tinggi sehingga menghambat aktifitas dan pertumbuhan khamir, tetapi disebabkan oleh kondisi buah yang sangat asam mengharuskan pemberian gula serta waktu fermentasi yang lebih lama.

\section{Tingkat Kesukaan}

Nilai tertinggi tingkat kesukaan pada perlakuan 50\% dengan tingkat agak suka dan nilai 
terendah terdapat pada perlakuan gula 30\% (tidak suka sampai agak suka). Penilaian panelis terhadap tingkat kesukaan anggur buah tomi-tomi adalah pemberian gula 50\% lebih disukai dibandingkan dengan pemberian $40 \%$ dan $30 \%$. Hal ini berhubungan erat dengan penerimaan panelis terhadap warna, aroma dan terutama rasa anggur tomi-tomi yang dihasilkan. Penilaian panelis terhadap penerimaan keseluruhan anggur tomi-tomi meningkat dengan semakin besarnya penambahan gula. Semakin tinggi penilaian panelis terhadap warna, aroma dan rasa maka semakin tinggi pula penilaian panelis terhadap penerimaan keseluruhan anggur tomi-tomi.

\section{Pengaruh Perlakuan Terhadap Sifat Kimia Anggur Buah Tomi-Tomi}

Berdasarkan hasil uji organoleptik maka perlakuan terbaik yang diperoleh adalah pemberian konsentrasi gula 50\% oleh karena itu perlakuan ini dipilih untuk dilakukan uji kimia anggur buah tomitomi.

\section{Kadar Etil Alkohol}

Berdasarkan uji kimia kadar etil alkohol yang dihasilkan dari anggur buah tomi-tomi masuk dalam standar mutu anggur rendah alkohol sesuai dengan SNI (1999) yaitu untuk anggur rendah alkohol etil alkohol maksimal 1,15\%. Adanya alkohol disebabkan oleh pemberian ragi dan juga dipengaruhi oleh proses fermentasi yang merupakan salah satu faktor dalam produksi kadar alkohol. Sehingga dalam proses fermentasi, $S$. cerevisiae yang memecah gula menjadi alkohol dan karbondioksida.

\section{Total Gula}

Total gula yang dihasilkan melalui proses fermentasi anggur buah tomi-tomi dari pemberian awal yang diberikan sebelum fermentasi $50 \%$, setelah melalui uji kimia maka total gula yang diperoleh dari anggur buah tomi-tomi adalah $21,23 \%$. Hasil penelitian menunjukkan bahwa terjadi perubahan pada gula awal menjadi total gula seiring dengan lamanya proses fermentasi dan pemberian ragi dalam pembuatan anggur buah tomi-tomi. S. cerevisiae mampu menggunakan sejumlah gula selama proses fermentasi dan dipecah menjadi etanol sehingga jumlahnya semakin berkurang. Karena gula digunakan sebagai sumber nutrisi untuk pertumbuhan $S$. cerevisiae dan pembentukan alkohol sebagai produk fermentasi, semakin besar jumlah pengurangan gula yang telah difermentasikan oleh $S$. cerevisiae maka alkohol yang terbentuk pun juga akan semakin tinggi. Pada proses fermentasi, gula digunakan oleh S.cerevisiae untuk dua hal yaitu untuk tumbuh dan berkembang biak, sebagian lagi akan dikonversi menjadi produk metabolit seperti alkohol.

\section{Derajat Keasaman}

Berdasarkan pengujian derajat keasaman pada anggur buah tomi-tomi dengan konsentrasi gula $50 \%$ terjadi penurunan nilai dari $\mathrm{pH}$ awal yang diatur hingga 3,75 (sebelum fermentasi) berubah menjadi 3,06 (setelah fermentasi). Semakin turunnya nilai $\mathrm{pH}$ pada produk anggur disebabkan oleh hasil fermentasi yang berupa etanol dan $\mathrm{CO}$ serta hasil-hasil metabolisme dari S. cerevisiae. Gas $\mathrm{CO}$ yang terbentuk akan bereaksi dengan molekul air $\left(\mathrm{H}_{2} \mathrm{O}\right)$ membentuk $\mathrm{H}_{2} \mathrm{CO}_{3}$ sebagai reaksi karbonasi yang ditandai dengan terbentuknya gelembung-gelembung gas dan akan terlepas jika tekanan dalam wadah lebih rendah dari tekanan atmosfir. $\mathrm{H}_{2} \mathrm{CO}_{3}$ akan memberikan suasana asam pada produk akhir sehingga produk akan memiliki nilai $\mathrm{pH}$ yang rendah. Selain itu adanya metabolit sekunder hasil fermentasi berupa asam-asam organik juga menyebabkan nilai $\mathrm{pH}$ menurun sehingga kandungan asam tinggi. Derajat keasaman $(\mathrm{pH})$ produk minuman juga dipengaruhi oleh adanya asam-asam organik seperti asam asetat dan asam piruvat yang terbentuk selama proses fermentasi. Keberadaan oksigen juga akan mengoksidasi etanol menjadi laktat sehingga nilai $\mathrm{pH}$ medium menjadi menurun dan kandungan asamnya tinggi. Pemberian gula dalam pembuatan anggur tomi-tomi bertujuan untuk memacu aktifitas S. cerevisiae hingga akan menghasilkan alkohol dalam proses fermentasi.

\section{KESIMPULAN}

1. Berdasarkan hasil uji organoleptik dapat disimpulkan bahwa perlakuan konsentrasi gula $50 \%$ merupakan perlakuan terbaik yang menghasilkan anggur buah tomi-tomi dengan warna agak merah sampai merah, aroma beralkohol, nilai rasa agak manis, dan tingkat kesukaan agak suka.

2. Konsentrasi gula 50\% menghasilkan kadar etil alkohol sebesar $1,27 \%$, kadar gula $21,23 \%$ dan 
pH 3,06 dan telah memenuhi SNI sebagai anggur rendah alkohol dengan kadar etil maksimal $1,15 \%$.

\section{DAFTAR PUSTAKA}

Ariyanto, H.D., F. Hidayatulloh, dan J. Murwono. 2013. Pengaruh penambahan gula terhadap produktivitas alkohol dalam pembuatan wine berbahan apel buang (reject) dengan menggunakan Nopkor MZ.11. Jurnal Teknologi Kimia dan Industri 2: 226-232.

[BSN] Badan Standardisasi Nasional. 1999. SNI Anggur Rendah Alkohol No 01-6103-1999.

Gaman, P.M. dan K.B. Sherrington. 1992. Ilmu Pangan: Pengantar Ilmu Pangan Nutrisi dan Mikrobiologi, Edisi Kedua. Diterjemahkan dari Buku The Service of Food, an Introduction to Food Science, Nutrition and Microbiology oleh Murdijati Gardjito, dkk. Gadjah Mada University Press. Yogyakarta

Gunam, I.B.W. dan L.P. Wrasiati. 2009. Pengaruh jenis dan jumlah penambahan gula pada karakteristik wine salak. Agrotekno 15: 1219.

Kourkoutas, Y., M. Kanellaki, A.A. Koutinas, and C. Tzia. 2006. Effect of storage of immobilized cells at ambient temperature on volatile by-products during wine-making. Journal of Food Engineering 74: 217- 223

Pawignya, H., T.W. Widayati, D. Putra, dan P. Akbar. 2010. Tinjauan Kinetika Pembuatan
Rose Wine. Prosiding Seminar Nasional Teknik Kimia "Kejuangan". Universitas Pembangunan Nasional Veteran. Yogyakarta. E07: 1-8.

Rahayu, E.S. dan K.R. Kuswanto. 1988. Teknologi Pengolahan Minuman Beralkohol. PAU Pangan dan Gizi. Universitas Gadjah Mada, Yogyakarta

Rubianty dan B. Kaseger. 1985. Kimia Pangan. Badan Kerja Sama Perguruan Tinggi Negeri Indonesia Bagian Timur. Ujung Pandang.

Said, E.G. 1987. Teknologi Fermentasi. CV Rajawali. Jakarta.

Santi, S.S. 2008. Pembuatan alkohol dengan proses fermentasi buah jambu mete oleh khamir Sacharomices cerevisiae. Jurnal Penelitian Ilmu Teknik 8: 104-111

Wahono, S.K., E. Damayanti, dan V.T. Rosyida. 2011. Laju Pertumbuhan Saccharomyces cereviseae Pada Proses Fermentasi Pembentukan Bioetanol dari Biji Sorgum (Sorghum bicolor L.). Seminar Rekayasa Kimia dan Proses. D-04: 1-6.

Widiastuti, D. dan P. Eska. 2010. Proses Pembuatan Anggur dari Buah Rambutan. Jurusan Teknik Kimia Fakultas Teknik, Universitas Diponegoro. Semarang.

Winarno, F.G. 2002. Kimia Pangan dan Gizi. Gramedia Pustaka Utama. Jakarta

Winarno F.G. 2004. Kimia Pangan dan Gizi. PT Gramedia Pustaka Utama. Jakarta. 